\title{
Discoveries and application of prostate-specific antigen, and some proposals to optimize prostate cancer screening
}

This article was published in the following Dove Press journal:

Cancer Management and Research

10 May 2016

Number of times this article has been viewed

\author{
Shinkan Tokudome' \\ Ryosuke Ando ${ }^{2}$ \\ Yoshiro Koda ${ }^{3}$ \\ 'Department of Nutritional \\ Epidemiology, National Institute of \\ Health and Nutrition, Shinjuku-ku, \\ Tokyo, ${ }^{2}$ Department of Nephro- \\ urology, Nagoya City University \\ Graduate School of Medical Sciences, \\ Mizuho-ku, Nagoya, ${ }^{3}$ Department \\ of Forensic Medicine and Human \\ Genetics, Kurume University School \\ of Medicine, Kurume, Japan
}

\begin{abstract}
The discoveries and application of prostate-specific antigen (PSA) have been much appreciated because PSA-based screening has saved millions of lives of prostate cancer (PCa) patients. Historically speaking, Flocks et al first identified antigenic properties in prostate tissue in 1960. Then, Barnes et al detected immunologic characteristics in prostatic fluid in 1963. Hara et al characterized $\gamma$-semino-protein in semen in 1966, and it has been proven to be identical to PSA. Subsequently, Ablin et al independently reported the presence of precipitation antigens in the prostate in 1970. Wang et al purified the PSA in 1979, and Kuriyama et al first applied an enzyme-linked immunosorbent assay for PSA in 1980. However, the positive predictive value with a cutoff figure of $4.0 \mathrm{ng} / \mathrm{mL}$ appeared substantially low $(\sim 30 \%)$. There are overdiagnoses and overtreatments for latent/low-risk PCa. Controversies exist in the PCa mortality-reducing effects of PSA screening between the European Randomized Study of Screening for Prostate Cancer (ERSPC) and the US Prostate, Lung, Colorectal, and Ovarian (PLCO) Cancer Screening Trial. For optimizing PCa screening, PSA-related items may require the following: 1) adjustment of the cutoff values according to age, as well as setting limits to age and screening intervals; 2) improving test performance using doubling time, density, and ratio of free: total PSA; and 3) fostering active surveillance for low-risk PCa with monitoring by PSA value. Other items needing consideration may include the following: 1) examinations of cell proliferation and cell cycle markers in biopsy specimens; 2) independent quantification of Gleason grading; 3) developing ethnicity-specific staging nomograms based on tumor stage, PSA value, and Gleason score; 4) delineation of the natural history; 5) revisiting the significance of the androgen/ testosterone hypothesis; and 6) devoting special attention to individuals with a certain genetic predisposition. Finally, considering the uncertainty that exists in medicine, risk communication on PSA-based screening is indeed due.
\end{abstract}

Keywords: application, benefits and harm, discovery, optimization, PCa screening, PSA

\section{Commentary}

The discoveries and application of prostate-specific antigen (PSA) have been much welcomed because of the hundreds of thousands of prostate cancer (PCa) patients whose lives have been saved by PSA-based screening. However, the early PSA discoveries, in particular, have still not been fully acknowledged. ${ }^{1}$ In 1960 , Flocks et al ${ }^{2}$ first identified antigenic properties in prostate tissue, while the immunologic characteristics in prostatic fluid were detected by Barnes et $\mathrm{al}^{3}$ in 1963. In 1966, Hara et $\mathrm{al}^{4}$ isolated and characterized $\gamma$-semino-protein in semen for judgment in forensic cases, and it has been proven to be identical to PSA. Subsequently, Ablin et al ${ }^{5}$ in 1970 independently reported the presence of precipitation antigens in the prostate. Although these
Correspondence: Shinkan Tokudome Department of Nutritional Epidemiology, National Institute of Health and Nutrition, I-23-I,Toyama, Shinjuku-ku, Tokyo 162-8636, Japan

Tel +8I 33203572 I

Fax +81332023278

Email tokudome2013@gmail.com
Cancer Management and Research 2016:8 45-47

(c) (i) (2) ( 2016 Tokudome et al. This work is published and licensed by Dove Medical Press Limited. The full terms of this license are available at https://mwr.dovepress.com/ cc. work you hereby accept the Terms. Non-commercial uses of the work are permitted without any further permisision from Dove Medical Press Limited, provided the work is property attributed. For permission for commercial use of this work, please see paragraphs 4.2 and 5 of our Terms (https://www.doveperess.com/terms.php).
Dovepress

http://dx.doi.org/10.2147/CMAR.S98326
45 
discoveries were not specifically related to $\mathrm{PCa}$, the keen observations are valuable. On the basis of these findings and subsequent investigations, Wang et al, ${ }^{6}$ from Chu's laboratory, purified the PSA in 1979, and Kuriyama et al ${ }^{7}$ in 1980 first developed and applied a sensitive serum immunoassay in PSA testing.

Considering that PSA testing is required as part of a screening battery, $\mathrm{PCa}$ is now a disease of priority calling for early detection and treatments. The PSA test is safe and less expensive. However, the test performance of positive predictive value with a cutoff figure of $4.0 \mathrm{ng} / \mathrm{mL}$, in particular, appeared rather low $(\sim 30 \%){ }^{8}$ There are overdiagnoses (overexaminations and overdetections) and overtreatments for latent/low-risk PCa: that is, the ratio of benefits: harm is not necessarily high. In other words, there are substantial false positives, whereas a high prevalence of $\mathrm{PCa}$ is observed in hypogonadal men with PSA level of $\leq 4.0 \mathrm{ng} / \mathrm{mL} .{ }^{9}$ Controversies exist in the PCa mortality-reducing effects of PSA screening between the European Randomized Study of Screening for Prostate Cancer (ERSPC) ${ }^{10}$ and the US Prostate, Lung, Colorectal, and Ovarian (PLCO) Cancer Screening Trial, ${ }^{11}$ and in the interpretations between the Japanese Urological Association ${ }^{12}$ and a research group functioning under the auspices of the Ministry of Health, Labour and Welfare (MHLW), Japan. ${ }^{13}$ Therefore, PSA testing has not been listed as a population-based screening instrument by the MHLW. ${ }^{14}$

Therapeutic schemes of PCa are literally advancing day by day, while management of PSA-based screening still seems to be developing. Administering PSA testing as the core, collaborative efforts should be used to standardize PCa screening for tailor-made treatments. ${ }^{15}$ PSA-related items and auxiliary biomarkers, such as in ongoing trials, may require the following: 1) adjustment of the cutoff values according to age, as well as setting limits to age and screening intervals; 2) improving test performance not only using doubling time (growth speed), density, and ratio of free: total PSA but also adopting validated assays for proenzyme PSA (pro-PSA), together with urinary markers including prostate cancer antigen 3 (PCA3); and 3 ) fostering active surveillance ${ }^{16}$ for low-risk PCa with close monitoring by PSA value because radical therapies, instead of active surveillance, have sometimes been used for such cases. Other items needing consideration may include the following: 1) examinations of cell proliferation and cell cycle markers in biopsy specimens; 2) independent (or automated) quantification of Gleason grading, when distinguishing the score $3+4$ from $4+3$ for Gleason grade 7 , as a typical instance, because the score is directly associated with decision making on treatment modalities; 3) developing ethnicity-specific staging nomograms ${ }^{17}$ based on tumor stage, PSA value, and Gleason score; 4) delineation of the natural history of PCa having a wide spectrum of the grade of malignancy; 5) revisiting the significance of the androgen/testosterone hypothesis in the phase of tumor initiation or promotion/progression, ${ }^{18}$ including levels of free and conjugated testosterone, as well as the ratio of testosterone/dehydroepiandrosterone (DHEA) or testosterone/estrogen; and 6) paying special attention to individuals with a PCa family history or genetic predisposition, including cancer-causing genes/single-nucleotide polymorphisms, tumor suppressor genes, or genetic polymorphisms associated with metabolisms of steroids and testosterone, alcohol, and vitamin D.

Uncertainty still exists in medicine and there are limits to human knowledge. Informed consent, informed choice, or risk communication (informed decision making) on PSAbased screening are indeed due, as observed in the recommendations recently released by the American Urological Association: "Offer PSA testing for detecting PCa only after engaging in shared decision making." ${ }^{19}$ Collaborative attempts should also be made to optimize (ie, maximize pros and minimize cons) $\mathrm{PCa}$ screening and to elaborate upon best-available therapies not only for reducing $\mathrm{PCa}$ mortality, prolonging patients' healthy life expectancy, and enhancing quality of life but also for downsizing health care expenditures.

\section{Disclosure}

The authors report no conflicts of interest in this work.

\section{References}

1. Rao AR, Motiwala HG, Karim OMA. The discovery of prostate-specific antigen. BJU Int. 2007;101:5-10.

2. Flocks RH, Urich VC, Patel CA, Opitz JM. Studies on the antigenic properties of prostatic tissue. I. J Urol. 1960;84:134-143.

3. Barnes GW, Soanes WA, Mamrod L, Gonder MJ, Shulman S. Immunologic properties of human prostatic fluid. J Lab Clin Med. 1963;61: 578-591.

4. Hara M, Inoue T, Koyanagi Y, Gotoh J, Yamazaki H, Fukuyama T. Preparation and immunoelectrophoretic assessment of antisera to human seminal plasma [Abstract in Japanese]. Nippon Hoigaku Zasshi. 1966; 20:356.

5. Ablin RJ, Bronson P, Soanes WA, Witebsky E. Tissue- and speciesspecific antigens of normal human prostate tissue. J Immunol. 1970;104: 1329-1339.

6. Wang MC, Valenzuela LA, Murphy GP, Chu TM. Purification of a human prostate specific antigen. Invest Urol. 1979;17:159-163.

7. Kuriyama M, Wang MC, Papsidero LD, et al. Quantitation of prostatespecific antigen in serum by a sensitive enzyme immunoassay. Cancer Res. 1980;40:4658-4662.

8. Hoffman RM. UpToDate ${ }^{\circledR}$ Screening for prostate cancer. Available from: http://www.uptodate.com/contents/screening-for-prostate-cancer. Accessed October 15, 2015. 
9. Morgentaler A, Rhoden EL. Prevalence of prostate cancer among hypogonadal men with prostate-specific antigen levels of $4.0 \mathrm{ng} / \mathrm{mL}$ or less. Urology. 2006;68:1263-1267.

10. Schröder FH, Hugosson J, Roobol MJ, et al; ERSPC Investigators. Screening and prostate-cancer mortality in a randomized European study. N Engl J Med. 2009;360:1320-1328.

11. Andriole GL, Crawford ED, Grubb RL 3rd, et al; PLCO Project Team. Mortality results from a randomized prostate-cancer screening trial. N Engl J Med. 2009;360:1310-1319.

12. The Committee for Establishment of the Guidelines on Screening for Prostate Cancer and Japanese Urological Association. Updated Japanese Urological Association Guidelines on prostate-specific antigen-based screening for prostate cancer in 2010. Int J Urol. 2010;17:830-838.

13. Hamashima C, Nakayama T, Sagawa M, Saito H, Sobue T. The Japanese guideline for prostate cancer screening. Jpn J Clin Oncol. 2009;39: 339-351.

14. Ministry of Health, Labour and Welfare, Japan. Practice of Cancer Screening in Municipalities in 2008 [in Japanese]. Available from: http://www.mhlw.go.jp/bunya/kenkou/dl/gan_kenshin02.pdf. Accessed October 15, 2015.
15. Cuzick J, Thorat MA, Andriole G, et al. Prevention and early detection of prostate cancer. Lancet Oncol. 2014;15:e484-e492.

16. Bul M, Zhu X, Valdagni R, et al. Active surveillance for low-risk prostate cancer worldwide: the PRIAS study. Eur Urol. 2013;63:597-603.

17. Partin AW, Mangold LA, Lamm DM, Walsh PC, Epstein JI, Pearson JD. Contemporary update of prostate cancer staging nomograms (Partin Tables) for the new millennium. Urology. 2001;58:843-848.

18. Mathew P. The bifunctional role of steroid hormones: implications for therapy in prostate cancer. Oncology (Williston Park). 2014;28: $397-404$.

19. American Urological Association [webpage on the Internet]. As Part of Choosing Wisely ${ }^{\mathbb{R}}$ Campaign, American Urological Association Identifies Second List of Commonly Used Tests and Treatments to Question. Available from: http://www.auanet.org/advnews/press_releases/article. $\mathrm{cfm} ? \operatorname{articleNo}=427$. Accessed October 15, 2015.
Cancer Management and Research

\section{Publish your work in this journal}

Cancer Management and Research is an international, peer-reviewed open access journal focusing on cancer research and the optimal use of preventative and integrated treatment interventions to achieve improved outcomes, enhanced survival and quality of life for the cancer patient The journal welcomes original research, clinical \& epidemiological

\section{Dovepress}

studies, reviews \& evaluations, guidelines, expert opinion \& commentary, case reports \& extended reports. The manuscript management system is completely online and includes a very quick and fair peerreview system, which is all easy to use. Visit http://www.dovepress.com/ testimonials.php to read real quotes from published authors. 